\section{Distinguishing fraud from error}

SIR - There is a danger in the controversy over fraud in science of merging the concepts of fraud and error. The call for an audit of scientific papers for error is a symptom of this trend. Fraud such as fabricating data or publishing the work of others as one's own is of course serious, particularly when it involves assessment of drugs and other medical treatments where lives are at stake. But error is an inevitable part of science. This fundamental point is heing missed in the current debate. Scientists struggle to express their ideas, struggle with recalcitrant organisms, use advanced laboratory techniques that they barely understand, and study systems so complex that many hypotheses may seem to fit the data. This is not the orderly process that some imagine science to be One does not go into a laboratory and order a cure for heart disease and get a guaranteed result. Results in science are never guaranteed and are never free from error. Newton, Einstein and Darwin were all wrong in some respects, even though they are the standard by which we judge genius itself

Science is a complex and subjective process, one man's enthusiastic promotion of an hypothesis may be another man's fraud. The history of science is full of individuals who turned out to be right but who, by the strict criteria proposed by some today, could be attacked for fraud. In the laboratory notebooks of Millikan's oil-drop experiments, it can be seen that he rejected many trials because his judgement told him that something was wrong. In today's climate he could be accused of blatant manipulation of the data, that is, fraud. The 'discoverer' of N-rays had bad technique and practised self-deception, but there was no fraud. Was Columbus guilty of scientific misconduct for his selfdelusion about the circumference of the Earth? Kepler defended himself in his search for the "Music of the Spheres".

Some of the charges levelled in recently publicized cases include misclassification of control subjects, poor laboratory procedure (Benveniste) and complex issues of scientific method (Baltimore). These are real scientific issues, but not causes for hand-wringing and raised eyebrows, much less for congressional scrutiny.

Who ever said that when you open a journal you are reading a message carved in stone by some higher being? Every time one reads the scientific literature, it is necessary to be wary and to compare, test and evaluate methods, data and statistical methods. At no point do we have such a grasp on the truth, statistical, experimental or otherwise, that a panel can be certified as error hunters. Reviewers of a paper are themselves often wrong (the original theory of continental drift was met by howls of laughter from 'respected' scientists). Who will review the error hunters? Who is qualified to punish whom?

So, is there error? Of course there is. But we should also note that every building built has flaws and half of them are ugly, every economic policy ever formulated is imperfect. We can only ask for perfection when the correct answer is known (for example, on the factory assembly line), but if the answer is known then it isn't science.

\section{Environmental Sciences}

Division, 773-42A,

Savannah River Plant,

Aiken, South Carolina 29808-0001, USA

\section{Defence research}

$\mathrm{S}_{\mathrm{IR}}$-You report (Nature 336, 610; 1988) that the veterinary school at this university is being supported in a research project on the survival of bacterial pathogens in aerosols by the Ministry of Defence (MoD) Chemical Defence Establishment. The project is of evident relevance to biological warfare, if for no other reason than that proposals must have 'defence relevance' to qualify for MoD support. Whether or not the ministry's interests in biological warfare are legitimate, we believe that they are not appropriate to a veterinary school.

Unlike the research councils, MoD has no remit to improve animal health and welfare nor a broad peer-group-defined strategy. The medical and veterinary benefits of the Bristol project are merely a spin-off of its defence interests.

While research support by the research councils appears to be increasingly inadequate, MoD support of research in British universities and higher education establishments has increased by 60 per cent since $1984-85$ (from $£ 10$ million to $£ 16$ million). Consequently there is a danger that scientists are relying increasingly, as at Bristol, on support from government or from commercial organizations with narrow research objectives and a strong interest in confidentiality, even secrecy. We believe that such support undermines the integrity and openness with which research can be conducted.

Clearly, the freedom with which a project is formulated is compromised when it has to conform to concerns of a sponsor (for example, defence or financial profit) that are completely irrelevant to the purpose of the research (for example, the improved health of livestock). The freedom to publish is not adequate safeguard of independence when the freedom to propose is restricted.

We urge research institutions and individuals to take a long hard look at the way in which the motives of funding bodies may subtly redirect and compromise research priorities and independence. Peter Dukes, Susan Mayer, Alison Blaxter, Helen Broadhead, Mark J. Newton-Clarke, Bevis Miller, Karen Stevens, A. Douglas WILSON, PAUL R. WOTTON, JOSEPH J. McNamara, Esbjorn Telemo, Martin Warnes School of Veterinary Science, University of Bristol, Langford House, Langford, Bristol BS18 7DU, UK

\section{Imperial Japan}

SIR-We should like to comment on the article (Nature 337, 107; 1989) in which Japan's deceased Emperor Hirohito was described as an admirable biologist. We fear that the article may be abused by those who wish to enhance or maintain the emperor system, and that it is likely to bc citcd in scntences such as "A leading scientific journal, Nature, also admires the Emperor as a prominent biologist'.

Since Hirohito died on 7 January, programmes on television and articles in newspapers and magazines have been full of admiration and glorification for the personal qualities of the emperor. Neither the mass media nor leading intellectuals have touched on the dangerous and inadequate aspects of the emperor system, which have been used to control the ideology and attitude of Japanese citizens. Opinions against the emperor or the emperor system are suppressed by both direct and indirect pressure.

There are some problems in associating biology with the emperor. First, the words 'naturalist' or 'biologist' give a relatively good impression, and have been used to make an admirable personality of the emperor. Second, there are few faculty positions and departments in the fields of fundamental biology (except biotechnology and molecular biology) and funds are also scarce in Japan. But biologists can get money for international meetings, and other scientific activities in subjects related to those in which the emperor was interested. So some biologists have tended to use the emperor to get funds, while the government and conscrvative intellectuals have used such biologists and their activities to enhance the respectable image of the emperor. The International Biological Prize (established to celebrate the sixtieth year of the emperor's reign) is also used to enhance the image of Japan's emperor in the eyes of other countries.

MASAKADO KaWATA

Department of Biology,

Faculty of Education.

Shizuoka University,

Oya, Shizuoka 422, Japan

Laboratory of Biology,

Faculty of Education,

Niigata University,

Ikarasi, Niigata 950-21, Japan 